Lenni Lestari

\title{
EPISTEMOLOGI HADIS PERSPEKTIF SYI‘AH
}

\author{
Lenni Lestari \\ Program Studi Ilmu Alquran dan Tafsir Fakultas Ushuluddin Adab dan Dakwah IAIN Langsa \\ Kampus Zawiyah Cot Kala Jl. Meurandeh, Langsa, 24411, Aceh, Indonesia \\ Email: lenny_jeumpa@yahoo.com
}

\begin{abstract}
One of shahih hadith -hadith of Saqalain- has brought moslem apart into two groups, Syi 'ah and Sunni. This disintegration implied to the hadith paradigm of each group. The paper discusses about epistemology of hadith of Syi 'ah. It analyzes the source and essence of hadith, the methodology of hadith, and validity of hadith in Syi 'ah's perspective. To make it clear, the paper describes one of example of Syi 'ah hadith. Judging from the aspect of epistemology, the main source of Shi'a hadith is not only from the Holy Prophet alone, but was extended to the priests who form a total of 12 Imams. The method used by Shia in obtaining the hadith is through history. Related to this, the Shia group divides the Hadith into two types, namely muthatih and ahad. The method used by Shi'a scholars in the validity of the authenticity of the hadith is to examine the narrations in which the sanad continues with the ma'sum, all the narrators in the sanad are fair and all the narrators in the sanad are dabit.
\end{abstract}

Keywords: Syi'ah, Hadith, Epistemology

\begin{abstract}
Abstrak
Salah satu hadis Nabi -hadis Saqalain-, yang diakui shahih oleh semua ulama hadis, telah membuat umat Islam terpecah menjadi dua aliran besar, yaitu Syi 'ah dan Sunni. Perbedaan ini berimplikasi pada pemikiran hadis dari kedua aliran ini. Tulisan ini akan membahas pemikiran hadis perspektif Syi'ah dari aspek epistemologi, meliputi sumber dan hakikat hadis perspektif Syi'ah, metodologi kajian hadisnya, serta validitas otentisitas hadis dalam tradisi Syi'ah. Di akhir pembahasan, penulis juga memberikan salah satu contoh hadis dari kitab hadis Syi 'ah. Ditinjau dari aspek epistemology, sumber utama hadis Syi 'ah tidak hanya dari Nabi saw semata, melainkan diperluas kepada imam-imam yang ma'shum yang berjumlah 12 imam. Metode yang digunakan Syi 'ahdalam memperoleh hadis adalah melalui jalur riwayat. Terkait hal ini, golongan Syi ah membagi hadis menjadi dua macam, yaitu mutawatir dan ahad. Cara yang digunkan ulama Syi'ah dalam validitasi otentisitas hadis adalah memeriksa riwayat yang sanadnya bersambung dengan yang ma'sum, seluruh periwayat dalam sanad bersifat adil dan seluruh periwayat dalam sanad bersifat dabit.
\end{abstract}

Kata Kunci: Syi 'ah, Hadis, Epistemologi

\section{Pendahuluan}

Aliran Syi ${ }^{`} a^{1}{ }^{1}$ yang dianggap lawan dari aliran Sunni, memiliki akar sejarah masing-masing yang hingga kini masih

\footnotetext{
${ }^{1}$ Kata "Syī'ah" (الثيعة) bentuk tunggalnya adalah Syi'iy (شيعي) yang berarti kelompok atau golongan, dapat digunakan untuk seseorang, dua atau jamak, naik laki-laki maupun perempuan. Lois Ma'luf, Al-Munjid fi al-Lughah wa al-A'lam (Beirut: Dār al-Masyriq, 1973), 441. Sebagaimana dikutip oleh Fadil, SJ. Islam Syi'ah, Telaah Pemikiran
}

membuat jurang pemisah antara keduanya. Dasar keyakinan Syi'ah sangat sederhana, yaitu ayat al-Quran dan hadis Nabi yang secara langsung mengakui eksistensi aliran

Imamah Habib Husein al-Habsyi (Malang: UIN Maliki Press, 2010), 19. Istilah ini sudah dikenal dan dipergunakan sejak masa Nabi, bahkan juga terdapat dalam al-Quran (QS. Al-Shaffat: 83, Al-Qashash: 15, Al-An'àm: 159, dsb). Lihat Abu Bakar Aceh. Perbandingan Mazhab Syi'ah Rasionalisme dalam Islam (Semarang: Ramdhani. 1980), 10. 
ini. ${ }^{2}$ Salah satu dalil dalam Alquran adalah

QS. Al-Shaffat: 83,

$$
\text { وَإِنَّ مِنْ شِيعَتِهِ لَالَبْرَاهِيمَ }
$$

Dan Sesungguhnya Ibrahim benarbenar termasuk golongannya (Nuh)

Dan dalil dari hadis,

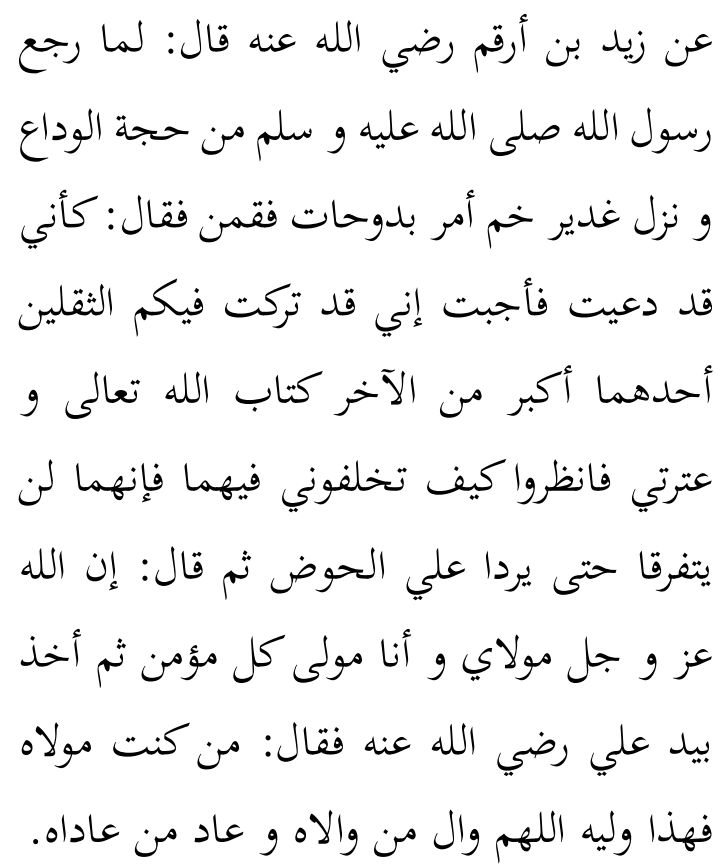

Kurasa seakan-akan segera akan dipanggil Allah dan segera pula aku akan memenuhi panggilan itu. Maka sesungguhnya aku meninggalkan kepadamu al-ŚSaqain, yang satu lebih besar dari yang kedua: yaitu Kitab Allah dan 'ithrah-ku. Jagalah baikbaik kedua peninggalan itu, sebab keduanya tak akan terpisah sehingga terkumpul kembali denganku di alHaudh. Kemudian beliau berkata lagi, sesungguhnya Allah adalah maulaku dan aku adalah maula bagi setiap mukmin, lalu beliau mengangkat

${ }^{2}$ Fadil, SJ. Islam, 20-28.

${ }^{3}$ Hadis ini diakui kesahihannya dalam kitab hadis Sunni dan Syi'ah. Lihat Muhammad bin 'Abdillah Abū 'Abdillah al-Ḥākim al-Naisaburiyyu, tangan Ali bin Abi Thalib sambil bersabda: "Barangsiapa yang mengganggap aku sebagai pemimpinnya, maka dia ini (Ali) adalah juga pemimpin baginya. Ya Allah, cintailah siapa pun yang mencintainya, dan musuhilah siapa pun yang memusuhinya"3

Dengan demikian sangat dipahami jika orang-orang Syi'ah begitu meyakini bahwa setelah wafatnya Rasulullah, kekhalifahan dan kepemimpinan umat Islam akan berada di tangan Ali. Tetapi realita berlawanan dengan harapan mereka.

Perbedaan pemahaman ini berimplikasi pada kodifikasi hadis. Syi‘ah menganggap bahwa hadis tidak hanya terbatas pada nabi saja, melainkan juga pada kedua belas imam keturunan dari Ali bin Thalib. Hal inilah yang menjadi perbedaan yang mendasar antara Syi'ah dan Sunni mengenai sumber hukum Islam kedua setelah al-Quran.

Imam Syi'ah terhenti hingga 12 orang karena imam yang ke-12 telah wafat saat masih kecil. Akan tetapi dalam doktrin Syi'ah Iśn̄a 'Asy'āriyah mengatakan, bahwa beliau adalah imam saat ini dan dialah Imam Mahdi yang dijanjikan. Menurut mereka, Imam Mahdi sekarang berada di dalam persembunyian dan akan muncul selama Allah mengizinkannya dan pada hari akhir,

Al-Mustadrak 'Alā al-Saḥihain, jilid III (Beirūt: Dār al-Kutub al-'Ilmiyyah, 1990), 118. Bandingkan dengan Ja'far al-Subhānī, Al-Hadīis al-Nabawìi, jilid XXXIV, (T.tp, T.th), 5 . 
kaum Syi'ah İंnā 'Asy'āriyah meyakini bahwa Imam al-Mahdi, Imam terakhir dari Imam Duabelas, akan menyelamatkan umat manusia dari kezaliman dan akan membangun suatu pemerintahan Islam.

Hal-hal penting dalam kajian Syi'ah, diantaranya adalah; 1) Syi'ah Zaidiyah merupakan aliran Syi 'ah yang bisa dikatakan sama dengan model Mu’tazilah akhir, yaitu yang melakukan perubahan dalam pemikiran mereka sebagai Syi'ah. 2) Tahun 284 H, al-Hādi ilāl-Haq mendirikan Syi‘ah Zaidiyah di Yaman. Sehingga lebih dikenal Syi ‘ah Hadawiyah. 3) Pada abad ini, mereka lebih terpengaruh dengan kitab-kitab hadis Ahlu Sunnah. 4) Pada abad ke-7, Syi‘ah Zaidiyah kembali berhasil mendirikan alirannya kembali, mereka menampakkan corak sunni agar dapat diterima. 5) AlShan'ani dan al-Syaukani merupakan ulama Syi`ah Zaidiyah. Tetapi sudah dianggap Sunni. Karena mereka telah dipengaruhi kekuasaan saat ini. 6) Abad ke-16, Iran baru mengubah mazhabnya menjadi Syi'ah,

${ }^{4}$ Pemikiran hadis yang dikaji dalam tulisan ini adalah fokus pada aliran Syi'ah Itsna 'Asyariah. Alasannya adalah: aliran ini paling masyhur dalam tradisi Syi'ah yang tersebar di berbagai negara Islam, bahkan menjadi mazhab resmi di Republik Islam Iran. Aliran ini terbentuk setelah lahirnya semua imam yang berjumlah dua belas, yaitu kira-kira pada tahun 260 H/878M. Heins Halm. Shiism. (Edinburg: Edinburg University Press. 1991), 29. Dikutip oleh Fadil, SJ. Islam, 62. Lihat Nurani Soyomukti. Pengantar Filsafat Umum: Dari Pendekatan Historis, Pemetaan Cabang-cabang Filsafat, Pertarungan Pemikiran, Memahami Filsafat Cinta, sebelumnya masih Sunni. Iran bisa dijadikan bukti kekuasaan mempengaruhi mazhab suatu negara.

\section{Pembahasan}

Berikut akan diulas tentang konstruksi epistemologi hadis perspektif Syi'ah, meliputi hakikat dan sumber hadis, metodologi dan validitas hadis.

\section{Hakikat dan Sumber Hadis}

Hadis dalam pandangan Syi ${ }^{\prime} \mathrm{ah}^{4}$ diartikan sebagai segala sesuatu yang disandarkan kepada yang ma'shūm, yaitu Nabi saw dan Imam dua belas, baik itu berupa perkataan, perbuatan, maupun ketetapan, dan dijadikan sebagai sumber hukum kedua setelah Alquran. ${ }^{5}$ Berdasarkan pengertian tersebut, maka sumber utama hadis tidak hanya dari Nabi saw. semata, melainkan diperluas kepada imam-imam yang ma'shüm yang jumlahnya 12 imam. $^{6}$ Selain itu, sejarah hidup para Ahlul Bait pun termasuk bagian dari sunnah (hadis). ${ }^{7}$

hingga Panduan Berfikir Kritis-Filosofis (Yogyakarta: Ar-Ruzz Media, 2011), 151-152.

${ }^{5}$ Hasan Amin. Däirat al-Ma'arifat alIslämiyyah al-Syì'iyyah, juz XI, jilid III (Beirūt: Dār al-Ta'arūf. 1971), 117. Sebagaimana dikutip Muhammad Alfatih Suryadilaga. Konsep Ilmu Dalam Kitab Hadis, Studi atas Kitab al-Käfi Karya alKulaini (Yogyakarta: TERAS, 2009), 62.

${ }^{6}$ Suryadilaga, Konsep, 62.

${ }^{7}$ Al-Kulaini, Al-Kafi, jilid I, (T.t.: T.p. T.Th.), 9. 
Epistemologi Hadis Perspektif Syi 'ah

Adapun sumber pengetahuan mengenai hadis-hadis Syi ‘ah dan kajiannya, dapat dijumpai dalam kitab-kitab hadis yang membahas ulumul hadis perspektif Syi'ah termasuk kitab-kitab yang menghimpun hadis-hadis yang ditransmisikan oleh perawi-perawi Syi'ah. Terkait hal ini, dalam bidang hadis, mereka mengenal al-Kutub al-Arba'ah (Kitab yang Empat), yaitu kitab al-Käfí karya Tsiqat alIslam, Muhammad ibn Ya'qub al-Kulayni al-Razi (w.940 M), kitab Man La Yahdhuruhu al-Fāqih karya Syaikh Shaduq Muhammad ibn Babawayh al-Qummi (w.991 M), kitab Tahdzib al-Ahkam karya Syaikh Abu Ja'far al-Țusi (w. 1068 M), dan kitab al-Istibșar karya Syaikh al-Ṭusi. ${ }^{8}$ Selain itu, mengenai sumber kajian ulumul hadis perspektif Syi'ah dapat dijumpai pada karya-karya, seperti; Kulliyāt fì ' $\mathrm{Ilm}$ alRijāl dan Usūl al-Hadis wa Ahkamuhu karya Ja'far al-Shubhani, Ma’a al-IśnāI al'Asyariyah fí Usūl wa al-Furū' karya 'Ali Aḥmad al-Sālūs, Qawā'id al-Hadì̉ karya Muhyi al-Dīn al-Mūsì al-Gharifí, dan lainlain.

Di bawah derajat ke-empat kitab ini, terdapat beberapa kitab Jami' yang besar, diantaranya:

${ }^{8}$ Husain Heriyanto, Revolusi Saintifik Iran (Jakarta: UI-Press, 2013), 21.
1. Kitab Bihārul Anwār disusun oleh Baqir al Majlisi. Terdiri dalam 26 jilid.

2. Kitab al-Wafie fi 'Ilmi al Hadis. Disusun oleh Muhsin al Kasyani. Terdiri dalam 14 juz. Ia merupakan kumpulan dari empat kitab hadist.

3. Kitab Tafshil Wasail Syi'ah Ila Tahsil Ahadist Syari'ah. Disusun oleh al-Hus al-Syāmi' al 'Amili. Disusun berdasarkan urutan tertib kitab-kitab fiqh.

4. Kitab Jami' Kabir yang dinamakan Asy-Syifa' fi Ahadis̈ al Muṣțafa. Susunan Muhammad Riḍa at-Tabrizi.

5. Kitab Jāmi' al-Aḥkām. Disusun oleh Muhammad al-Riḍā al-Tsairi al Kâdzimi (w.1242 H). Terdiri dalam 25 jilid.

Menurut Syi'ah, hakikat hadis mempunyai tiga jenis, pertama, riwayat yang mengandung petunjuk pembersihan jiwa, akhlak, nasehat, dan cara-cara pengobatan penyakit hati. Termasuk riwayat yang mengandung do'a, zikir, dan keutamaan ayat-ayat. Itu semua, menurut kaum Syi'ah bisa dijadikan landasan untuk beramal ibadah dan tidak perlu dicari tahu apakah sanad dan matannya shahih atau tidak. 
Kedua, riwayat yang mengandung hukum syara', seperti thaharah, berwudhu, cara shalat, zakat, transaksi yang diperbolehkan, nikah, thalaq, warisan, dan lain-lain. semua riwayat tersebut tidak boleh langsung dijalankan. Akan tetapi, terlebih dahulu diberikan kepada mujtahid untuk diterjemahkan. Sedangkan orang awam harus mengikuti mujtahid marji'. Ketiga, riwayat yang mengandung pokokpokok aqidah, seperti peng-itsbatkan alKhaliq, ḥasyr, barzakh, sirạt, mīzān, ḥisāb, dan lain-lain.

Jadi, pada hakikatnya, hadis menurut Syi'ah adalah riwayat yang ada kaitannya dengan akidah dan pokok agama mereka, seperti tauhid, 'adl, nubuwwah, imāmah, dan ma'ad. ${ }^{9}$ Jika riwayat tersebut sesuai dengan dalil-dalil 'aqli, urgensi, dan tanda-tanda yang qat' $i$, maka ia dapat dilaksanakan, tanpa perlu menyelidiki sanad. ${ }^{10}$

\section{Metode Kajian Hadis}

Metode yang dibahas dalam tulisan ini adalah metode Syi'ah dalam memperoleh hadis. Menurut penulis, metode yang digunakan Syi'ah dalam

${ }^{9}$ Lima poin ini merupakan ajaran dasar Syi'ah Itsna 'Asyariyah. Lihat Salman Ghaffari, Shi'aisme (Tehran: Haidari Press. 1959), 41-42. Dikutip oleh Fadil, SJ. Islam, 63.

${ }^{10}$ Wahyuni Shifatur Rahmah. Epistemologi Hadis Dalam Pandangan Sunni dan Syi'ah. Jurnal memperoleh hadis adalah melalui jalur riwayat. Terkait hal ini, golongan Syi'ah membagi hadis menjadi dua macam, yaitu mutāwatir dan ahāad. Hadis mutāwatir adalah hadis yang diriwayatkan oleh sekelompok orang banyak (dengan jumlah tertentu) yang tidak memungkinkan mereka sepakat untuk berdusta. Dalam hal ini, kalangan Syi‘ah tidak menetapkan berapa orang batasan minimal bagi hadis yang termasuk mutawatir.

Adapun hadis ahăd adalah hadis yang tidak mencapai derajat mutawatir, baik diriwayatkan oleh satu orang atau lebih. Hadis ahad terbagi menjadi empat macam, yaitu:

a. Hadis Sahih yaitu hadis yang ditransmisikan oleh rawi dari seorang imam yang dipastikan ke-'adalahannya melalui metode yang shahih, serta sanadnya bersambung dengan imam yang ma'shüm. ${ }^{11}$

b. Hadis Hasan, yaitu hadis yang ditransmisikan oleh rawi terpuji, bersambung dengan imam yang ma'shūm dan tidak ada cerita dari seorang pun mengenai cacat ke'adalah-annya.

Studi Ilmu-ilmu Al-Quran dan Hadis, Vol. 7, No. 2, Juli 2006, 255-256.

${ }^{11}$ Muḥyi al-Din al-Mūsi al-Gharifí, Qawa'id al-Hadis, jilid I (T.t.: t.p, t.th), 9. 
c. Hadis al-Muwāíśaq, yaitu hadis yang ditransmisikan oleh seorang rawi nonImamiyah akan tetapi ia siqah dan terpercaya serta diterima oleh golongan Syi'ah Imamiyah. Kalangan Syi'ah menolak secara mutlak hadis yang diriwayatkan oleh orang Sunni. Namun, ada juga yang mengatakan bahwa selama periwayat Sunni tidak dikenal karena kebenciannya pada Ahlul Bait Nabi saw dan dipercaya (adil), dia diterima oleh ahli hadis Syi ‘ah.

d. Hadis al-Dhā'if yaitu hadis yang ditransmisikan oleh rawi yang tidak memenuhi syarat tiga kriteria sebelumnya, seperti tidak beragama Islam, fasiq, majhūl, dan lainnya.

Berdasarkan pembagian di atas, maka dapat disimpulkan bahwa dalam memperoleh hadis, aspek kuantitas tidak selalu berbanding lurus dengan aspek kualitas. Menurut penulis, hal ini karena tidak semua hadis yang tidak mencapai derajat mutawatir, langsung dikategorikan tidak shahih. Maka dari itu, jika suatu hadis diriwayatkan dari sumber terpercaya, melalui imam tertentu dan ia adalah orang yang diakui ke-śiqahan-nya, serta sejalan dengan prinsip dasar ajaran mereka, maka

\footnotetext{
${ }^{12}$ Muhammad Abū Zahrā Al-Imām Al-Shadiq Hayātuhu wa Asruhu wa Fiqhuhu (Beirut: Dār alFikr, t.th.), 425-426. Sebagaimana dikutip Suryadilaga, Konsep, hlm. 63.
}

hadis tersebut dapat diterima, meskipun ditransmisikan oleh satu orang.

\section{Validitasi Otentisitas Hadis}

Cara yang lazim digunakan oleh ulama Syi'ah dalam melakukan penelitian sanad hadis adalah dengan memberikan kriteria-kriteria sebagai periwayat hadis, yaitu: ${ }^{12}$

a. Sanadnya bersambung dengan yang ma’sūm, yaitu Nabi saw, Ali bin Abi Thalib, dan Imam sebelas. Pada sanad terakhir yaitu Imam kedua belas, tidak disyaratkan harus bersambung dengan Nabi saw, karena pada hakikatnya segala yang disandarkan kepada Imam 12 adalah sunnah dan dapat dijadikan hujjah. ${ }^{13}$

b. Seluruh periwayat dalam sanad bersifat 'adil. Di dalam keadilan seorang periwayat, harus dipenuhi beberapa unsur lain sebagai pendukung, yaitu: 1) Beragama Islam. Keislaman merupakan salah satu unsur yang harus dipenuhi oleh periwayat yang 'adil. Golongan Syi'ah mendasarkan ketentuan ini, kepada adanya suatu keharusan untuk menetapkan diterimanya informasi dari orang fasiq. 2) Berstatus mukallaf.

${ }^{13}$ Ahmad Syarafuddin al-Musāwi, $A b \vec{u}$ Hurairah (Najaf: Masyūrat Maktabat al-Khiḍiyat. 1964), 174. Sebagaimana dikutip Muhammad Alfatih Suryadilaga. Konsep, 64. 
Dalam status ini terkandung dua sifat, yaitu berakal dan baligh. Maka dalam hal ini, tidak diterima khabar (hadis) dari orang gila dan anak kecil yan belum mencapai aqil baligh. Adapun anak-anak yang sudah aqil baligh, terdapat dua pendapat. Pendapat yang masyhur adalah tidak diterima hadisnya. 3) Beriman. Dalam hal imam, Syi'ah membatasi dalam periwayatan adalah kepercayaan tentang keberadaan Imam yang dua belas. Hal ini mempunyai tendensi bahwa tidak dibolehkannya mengamalkan hadis yang menyalahi kelompok Syi'ah. Rekomendasi seorang imam sangat berpengaruh sekali terhadap diterimanya suatu riwayat di kalangan ahli hadis Syi‘ah. 4) Al-wilayah, yaitu pengakuan bahwa kedua belas Imam sebagai pemimpin umat.

Menurut Syi'ah, ‘àdil terbagi menjadi dua, yaitu ' $\bar{A}$ dil mutlāq atau wasfiyah, yaitu para periwayat tidak menyeleweng dari faham mazhab Syi‘ah Imāmiah, dan 'àdil nisbiyah, yaitu para periwayat yang berlainan bidang aqidah dengan Syi'ah Imāmiyah.

\footnotetext{
${ }^{14}$ Muhammad Abū Zahrā. Al-Imām Al-Shadiq, 406-408, dalam Suryadilaga, Konsep, 71.

${ }^{15}$ Muhammad Abū Zahrā. Al-Imām Al-Shadiq Hayātuhu wa Asruhu wa Fiqhuhu (Beirut: Dār alFikr, t.th), 425-426. Dikutip oleh Rahmah, Epistemologi, 257.
}

3) Seluruh periwayat dalam sanad bersifat $d a b i \bar{t}$. Periwayat $d \bar{a} b i t$ dalam tradisi Syi 'ah adalah seorang yang hafal hadis yang diriwayatkan, terjaga benar-benar hafalannya dan menjaga ketimpanganketimpangan terhadap hadis yang diriwayatkan. Ke-dābit-an dapat rusak bila, lebih banyak salah daripada benar, lebih menonjol lupa daripada hafalnya, dan diduga keras mengandung kekeliruan, dan sudah tentu ini tidak lepas dari pantauan ulama Syi ${ }^{\prime} a h .{ }^{14}$

Melalui kriteria di atas, maka dapat disimpulkan bahwa hadis shahih menurut Syi'ah adalah hadis yang memiliki standar periwayatan yang baik dari imam-imam ma'shüm di kalangan mereka. ${ }^{15}$ Pengaruh Imamiyah di sini tampak pada pembatasan imam yang ma'shum dengan persyaratan periwayat harus dari kalangan Imamiyah. Jadi, hadis tidak sampai derajat shahih jika para periwayatnya bukan dari Ja'fariyah Isna 'Asy'ariyah dalam semua tingkatan. ${ }^{16}$

Tiga alasan fundamental yang menyebabkan golongan Syi ${ }^{`}$ ah menggunakan isnād pada sistem periwayatan mereka. ${ }^{17}$ Pertama, alasan

\footnotetext{
${ }^{16}$ Ali Ahmad al-Salus. Ensiklopedi SunniSyiah, Studi Perbandingan Hadis dan Fiqh (Jakarta: Pustaka al-Kautsar, 1997), 127. Dikutip oleh Rahmah, Epistemologi, 257.

${ }^{17}$ Abd al-Aziz A. Sachedina, "Signifikansi Rijāl Karya al-Kasysyi dalam Memahami Peran Awal
} 
psikologis, dalam mencantumkan sebuah isnād pada suatu riwayat hadis adalah menghubungkan periwayat mutaqaddimin dengan tokoh-tokoh terkesan di masa lalu yang mempunyai realibilitas dalam teks yang diriwayatkan. Berbekal alasan tersebut sebelum menerima apapun dari ilmu yang disampaikan melalui riwayat, dirasa perlu untuk menetapkan rantai periwayat yang membentuk sebuah hubungan, yang melalui mereka ini bagian pengetahuan bisa dijangkau.

Kedua, alasan ideologis. Dalam lingkungan intelektual, ulama Syi'ah banyak berdiskusi dengan ulama Madinah, Kuffah, dan Bagdad. Ada kekhawatiran terjadinya interpolasi ajaran-ajaran asli para Imam. Ketiga, alasan teologis, Isnād dalam sebuah riwayat hadis terdiri at as mata rantai periwayat yang menghubungkan hadis dengan sumber riwayat dipandang valid.

Terkait ilmu kritik hadis, kalangan Syi'ah juga menetapkan metodologi Ilmu Rijal, yaitu ilmu yang ditujukan untuk menguji ilmu dan keadaan para perawi saat menyampaikan hadis. Ilmu ini digunakan untuk mengetahui dan mengidentifikasi sebuah hadits itu shahih atau tidak menurut Syi'ah. Melalui metode ini dan berbagai rumusan pemikiran hadis di kalangan

Para Faqih (Fuqaha') Syi'ah" dalam al-Hikmah, No. 16, Vol. VII, 1996, 18. Suryadilaga, Konsep, 62-63.
Syi'ah, dapat disimpulkan bahwa kajian kritik hadis juga berkembang ketat di kalangan Syi`ah. Terutama dalam kajian sanad hadis, mereka akan benar-benar menyeleksi para perawi yang termasuk nonSyi`ah.

Dari aspek al-jarh dan al-ta'dil, maka dalam tradisi hadits Syi'ah, ke'adalah-an seorang perawi dapat ditetapkan dengan salah satu dari dua hal:

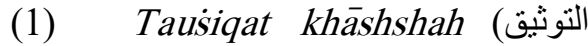
(الخاصنّ), yaitu sebuah pemberian rekomendasi untuk satu atau dua perawi tanpa adanya suatu predikat khusus untuk mereka. Sedangkan yang kedua adalah pemberian rekomendasi untuk sekelompok orang dengan batasan dan predikat khusus dan tertentu. ${ }^{18}$

Salah satu contoh tausiqat khașșah menurut mereka- adalah jika salah seorang imam ma'shum atau salah satu ulama terdahulu memberikan rekomendasi akan ketsiqahan seorang perawi. Maka dalam kondisi semacam ini, ketsiqahan orang itu harus ditetapkan tanpa banyak komentar.

$$
\text { Ja'far al-Subhany mengatakan, }
$$
metode-metode seperti ini adalah termasuk metode yang dapat menetapkan ke-siqah-an seorang perawi tanpa perlu komentar lagi.

\footnotetext{
${ }^{18}$ Tanpa pengarang. Mu'jam Muștahät alRijal wa al-Dirāyah, jilid IV (T.tp. T.th), 28.
} 


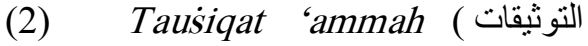
(العامة ), yaitu yang dengannya ke-śsiqah-an sekelompok perawi dapat ditetapkan. ${ }^{19}$

Adapun tautsiqat ammah yang dijadikan sandaran penting dalam madzhab Syi'ah Imamiyah, terdiri dari beberapa kelompok berikut:

Pertama, Aṣ̣āb al-Ijmā'. Mereka adalah kelompok yang disepakati (ijma) semua riwayat yang datang dari mereka adalah shahih. Rincian mereka adalah 6 orang dari murid-murid al-Baqir, 6 orang dari murid-murid al-Shadiq, dan 6 orang dari murid-murid Musa al-Kazhim.

Kedua, Masyāyikh al-ŚSiqat. Mereka adalah beberapa orang yaitu Muhammad ibn Abi Umair, Shafwan ibn Yahya, dan Ahmad ibn Muhammad ibn Abi Nashr al-Bizantyyang tidak meriwayatkan dan memursalkan sebuah hadits kecuali dari perawi yang tsiqah.

Ketiga, disamping ketiga nama di atas, ada pula beberapa nama yang dikenal tidak meriwayatkan hadits kecuali dari orang-orang yang tsiqah. Mereka adalah Ahmad ibn Muhammad ibn Isa, Jafar ibn Basyir al-Bajaly, Muhammad ibn Ismail alZafarany, dan Ahmad ibn Ali al-Najasyi.

Satu hal penting lain yang juga perlu disebutkan secara singkat di sini adalah sebab-sebab penetapan al-jarh terhadap seorang perawi, diantaranya adalah: 1) Akidah yang batil. Tentu yang dimaksud adalah jika sang perawi bukanlah pengikut Imamiyah. 2) Cacatnya keadalahan perawi, seperti jika ia melakukan dosa besar dan terus-menerus melakukan dosa kecil. 3) Hafalan yang buruk. 4) Jika seorang perawi banyak meriwayatkan dari perawi-perawi yang dhuafa dan majhulun (bodoh). 5) Jika perawi itu berasal dari kalangan Bani Umayyah, kecuali jika ia seorang pengikut Imamiyah.

Keseriusan mereka dalam merumuskan ilmu Rijal terlihat dari beberapa karya yang berbicara mengenai hal ini, diantaranya; Kitāb al-Rijāl, karya Ahmad bin 'Ali al-Najasyi (w.450 H.), Kitāb al-Rijäl karya Syaikh al Ṭusi, kitab Ma'älim 'Ulamā' karya Muhammad bin 'Ali bin Syahr Asyub (w.588 H.), kitab Minhaj al Maqāl karya Mirza Muhammad al Astrabady (w.1.020 H.), kitab Itqān al Maqāl karya Syaikh Muhammad Thaha Najaf(w.1.323 H.), dan kitab Rijāl al-Kabìr karya Syaikh Abdullah al Mumaqmiqani, seorang ulama abad ini.

\footnotetext{
${ }^{19}$ Ja'far. Durūs Müjizah fi 'Ilmī al-Rijal wa al-Dirāyah, jilid III (T.t.: t.p., t.th), 3 .
} 
4. Sikap Syi'ah Imamiyah Terhadap Teksteks Hadits Mereka

Sikap para ulama Syi‘ah dalam memandang dan menyikapi teks-teks hadits mereka sendiri, ternyata berbeda. Secara umum pandangan dan sikap yang berbeda ini terwakili dalam 2 kelompok besar, yaitu al-Ikhbariyyun dan al-Ushuliyyun. ${ }^{20}$

Kelompok al-Ikhbariyyun adalah kelompok Syi'ah Imamiyah yang melarang ijtihad dan mencukupkan diri dengan mengamalkan teks-teks hadits yang terdapat dalam empat kitab hadits mereka; al-Kafi, Man La Yahdhuruhu al-Faqih, al-Tahdzib dan alIstibshar.

Tidak hanya itu, mereka memandang bahwa apa yang terkandung dalam keempat kitab itu qath' $i$ berasal dari para imam, dan karena itu, mereka tidak perlu melakukan penelitian lebih lanjut tentang sanadnya. Demikian pula membagi hadits-hadits dalam kitab-kitab itu menjadi shahih, hasan, dhaif, dan sebagainya, sama sekali tidak perlu. Mengapa? Sebab semuanya shahih.

Mereka juga menggugurkan dalil ijmadan 'aqli. Ilmu Ushul fiqih tidaklah shahih, karena itu tidak perlu dipelajari. Intinya mereka mencukupkan diri dengan khabar-khabar yang terdapat dalam rujukan

\footnotetext{
${ }^{20}$ Bāqir al-Airuwānì, Durūs Tamhìdiyah fí alQawa'id al-Rijaliyah (T.t.: t.p., 1417 H), 47. Lihat
}

utama mereka. Karena itu mereka disebut juga al-Akhbariyah, sebuah penisbatan kepada al-akhbar (khabar-khabar). Tokoh-tokoh kelompok ini diantaranya adalah al-Kulainy (w. 329 H) penulis alKafy, Ibnu Babawaih al-Qummy (w. 382 H), penulis Man La Yahdhuruhu al-Faqih, dan al-Mufid (w. $413 \mathrm{H}$ ), penulis Awāl alMaqalat.

Sedangkan kelompok al-Ushuliyyun adalah mereka yang memandang perlunya ijtihad, ${ }^{21}$ dan bahwa landasan hukum itu terdiri dari al-Quran, al-Sunnah, ijma dan dalil 'aqli. Mereka juga meyakini bahwa hadits-hadits yang terdapat dalam keempat kitab pegangan itu, sanadnya ada yang shahih, hasan, dan dhaif. Oleh karena itu, diperlukan sebuah kajian terhadap sanadnya pada saat akan diamalkan atau dijadikan landasan hukum. Tokoh-tokoh kelompok ini antara lain adalah: al-Thusy (w. $460 \mathrm{H}$ ), penulis al-Istibshar, al-Murtadha yang dianggap menyusun Nahj al-Balaghah, Muhsin al-Hakim, al-Khuāiy dan alKhumainy (Khomeni).

Perbedaan ini bahkan sampai pada tingkat keluarnya fatwa keharaman untuk shalat di belakang satu sama lain, dan bahkan saling mengkafirkan satu sama lain.

juga Muhyi al-Din al-Mūsi al-Gharifí Qawa'ì alHadis, jilid VI (T.t.: t..p., t.th.), 1 .

${ }^{21}$ Tanpa pengarang. Al-Sayyid al-Murtadha, jilid II (T.t.: t.p., t.th.), 24. 
Meskipun keduanya masih termasuk dalam kelompok Imamiyah Itsna 'Asyariyah. Perpecahan ini diduga memuncak ketika salah seorang ulama hadits mereka, Muhammad Amin al-Astarabady (w. 1033H) melemparkan tuduhan dan tikaman kepada kelompok mujtahidin Syi'ah, yang kemudian membuatnya membagi kelompok Syi'ah menjadi Akhbari dan mujtahid. Tidak hanya itu, ia juga memprovokasi pengikutnya untuk menyerang ilmu Ushul fiqih dan mencukupkan diri dengan haditshadits mereka. ${ }^{22}$

\section{Contoh Hadis Syi 'ah}

Dalam tradisi Syi'ah, terdapat persoalan-persoalan mendasar yang wajib diketahui oleh setiap manusis yang berakal supaya ia dapat sampai pada kehidupan insaniyyah yang disenangi oleh akalnya. Tiga prinsip tersebut adalah yaitu mengesakan Tuhan (Tauhid), hari kiamat ( $\left.m a^{\prime} a d\right)$, dan kenabian (nubuwwah). Estafet ilmu selanjutnya adalah ulama yang merupakan pewaris para nabi. ${ }^{23}$ Pesan ini terdapat dalam sebuah hadis yaitu,

وعن محمد بن يحيى، عن أحمد بن محمد بن عيسى، عن محمد بن خالد، عن ابي البختري،

${ }^{22}$ Metodologi, 4-5.

${ }^{23}$ Suryadilaga, Konsep, 164-165.

${ }^{24}$ Muhammad bin al-Husain al-Ḥar al-'Āmili. Al-Fusul al-Muhimmah fí Ușul al-Aimmah, jilid I

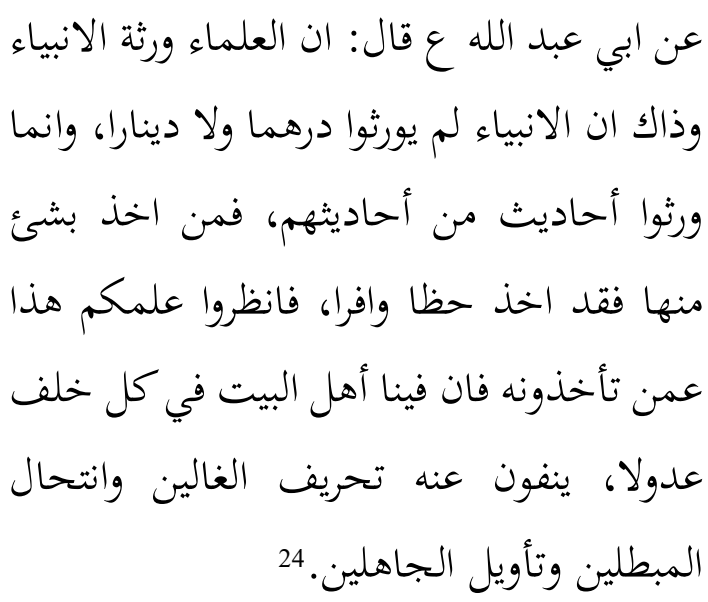

"Dari 'Abdillah 'alaihi al-salam berkata; Sesungguhnya ulama itu pewaris para nabi. Karena, sesungguhnya para Nabi tidak mewariskan dirham maupun dinar, melainkan mereka hanya meninggalkan hadis-hadisnya. Barangsiapa yang mengambil sesuatu darinya maka dia telah mengambil untung yang banyak. Perhatikanlah ilmu kalian, dari siapakan kalian mengambilnya?. Sungguh diantara kita ada Ahlul Bait. Pada setiap generasi ada orang-orang yang adil yang membersihka ilmu kita dari penyelewengan kaum ekstrim, manipulasi kaum sesat, dan interpretasi orang-orang bodoh".

Dari hadis di atas, tampak adanya hierarki tentang masalah kenabian. Kenabian yang diberikan kepada Nabi Muhammad saw, terus bergulir dan dilanjutkan oleh pewaris lain yaitu ulama. Termasuk di dalamnya, yang disebut sebagai pewaris adalah ahlul bait. Kesemuanya itu

(Nekin Qum: Muassasah Ma'ārif Islāmỉ Imām Reza, 1418), 495. 
sebagai tempat rujukan dalam rangka menjaga agama dari penyelewengan. ${ }^{25}$ Mandat khusus kepada ahlul bait inilah yang merupakan ciri khas hadis Syi`ah.

\section{Kesimpulan}

Dari pemaparan di atas dapat disimpulkan bahwa dari aspek epistemologi, maka sumber utama hadis tidak hanya dari Nabi saw. semata, melainkan diperluas kepada imam-imam yang ma'shum yang jumlahnya 12 imam. Hakikat hadis ada tiga, 1) Riwayat yang mengandung petunjuk pembersihan jiwa, akhlak, nasehat, dan caracara pengobatan penyakit hati. 2) Riwayat yang mengandung hukum syara' dan 3) Riwayat yang mengandung pokok-pokok aqidah. Metode yang digunakan Syi'ah dalam memperoleh hadis adalah melalui jalur riwayat. Terkait hal ini, golongan Syi`ah membagi hadis menjadi dua macam, yaitu mutâwatir dan ahäd. Cara yang lazim digunakan oleh ulama Syi'ah dalam melakukan penelitian sanad hadis adalah dengan memberikan kriteria-kriteria sebagai periwayat hadis, yaitu; 1) Sanadnya bersambung dengan yang ma'șum, 2) Seluruh periwayat dalam sanad bersifat 'adil, 3) Seluruh periwayat dalam sanad bersifat dabịt. Demikian pemaparan mengenai epistemologi hadis Syi'ah. Kritik dan saran kontruktif sangat penulis harapkan demi mencapai kesempurnaan tulisan ini.

\section{Daftar Pustaka}

Aceh, Abu Bakar. Perbandingan Mazhab Syi'ah Rasionalisme dalam Islam. Semarang: Ramdhani. 1980.

Al-Kulaini. Al-Kafi. Jilid I. T.t.: t.p., t.th.

al-Airuwāni, Bāqīr. Durūs Tamhīdiyah fī al-Qawā'id al-Rijaliyah. T.t.: t.p., 1417 H.

Heriyanto, Husain. Revolusi Saintifik Iran. Jakarta: UI-Press, 2013.

al-Subhāni, Ja'far. Al-Hadīi al-Nabawīi. T.t.: t.p., t.th.

Ja'far. Durūs Müjizah fì 'Ilmi al-Rijal wa al-Dirayah. Jilid III. T.t.: t.p., t.th.

\footnotetext{
${ }^{25}$ Suryadilaga, Konsep, 165.
} 
Muḥammad bin 'Abdillah Abū 'Abdillah al-Ḥākim al-Naisaburiyyu. Al-Mustadrak 'Alā alSahịhain. Beirūt: Dār al-Kutub al-'Ilmiyyah, 1990.

Muḥammad bin al-Ḥusain al-Ḥar al-‘Āmili. Al-Fusul al-Muhimmah fí Usūul al-Aimmah. Nekin Qum: Muassasah Ma’ārif Islāmỉ Imām Reza, 1418.

Muhyi al-Dỉn al-Mūsi al-Gharifí. Qawa'ìid al-Hadis. Jilid I. T.t.: t.p., t.th.

Muhammad Alfatih Suryadilaga. Konsep Ilmu Dalam Kitab Hadis, Studi atas Kitab al-Käfi Karya al-Kulaini. Yogyakarta: TERAS, 2009.

Nurani Soyomukti. Pengantar Filsafat Umum: Dari Pendekatan Historis, Pemetaan Cabangcabang Filsafat, Pertarungan Pemikiran, Memahami Filsafat Cinta, hingga Panduan Berfikir Kritis-Filosofis. Yogyakarta: Ar-Ruzz Media, 2011.

Tanpa pengarang. Al-Sayyid al-Murtadha. T.t.: t.p., t.th.

Wahyuni Shifatur Rahmah. Epistemologi Hadis Dalam Pandangan Sunni dan Syi‘ah. Jurnal Studi Ilmu-ilmu Al-Quran dan Hadis, Vol. 7, No. 2, Juli 2006. 
Epistemologi Hadis Perspektif Syi 'ah 